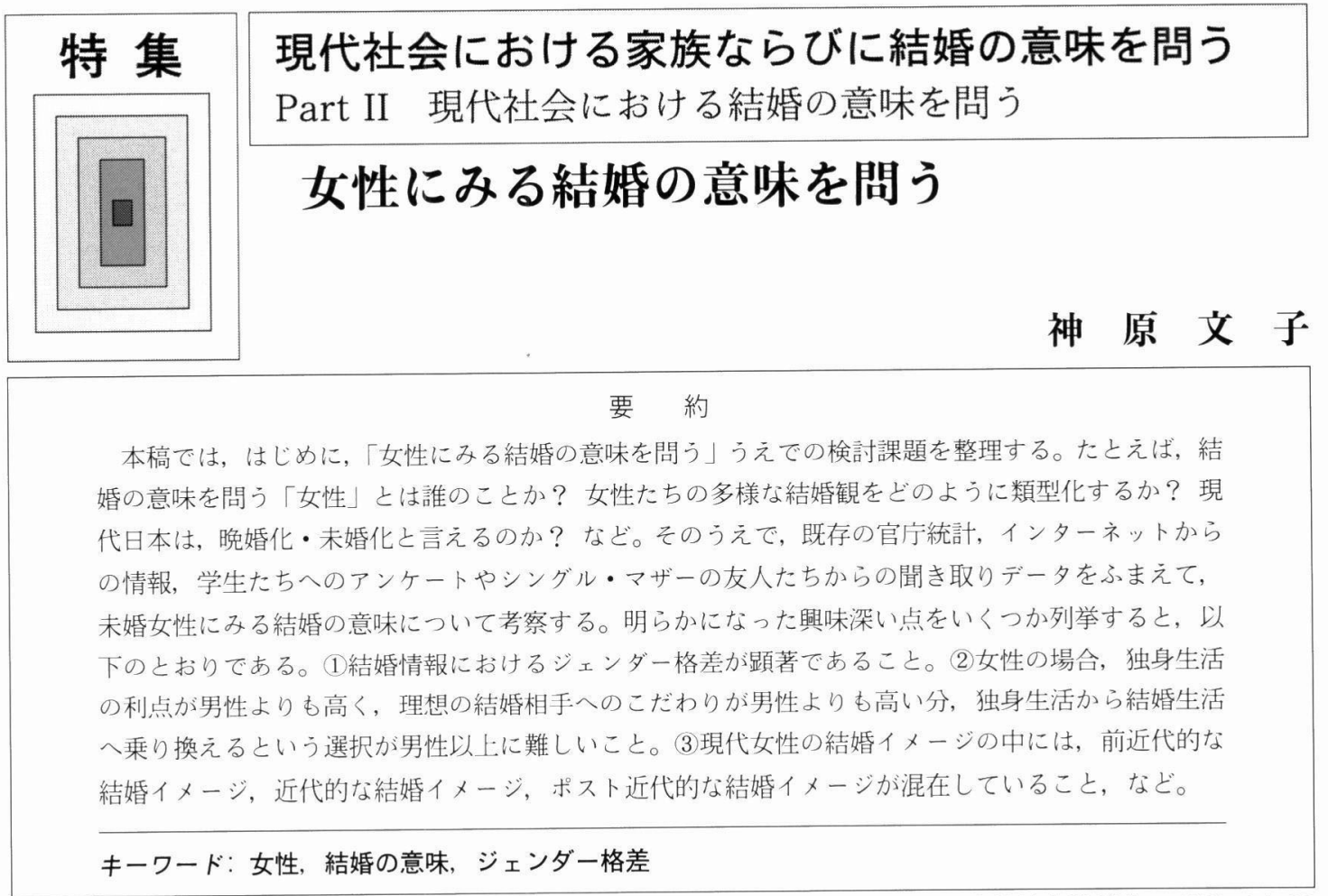

2004, 家族社会学研究, 15(2): 14-23

\title{
Considering the Meaning of Marriage as Observed in Women
}

Fumiko Kambara

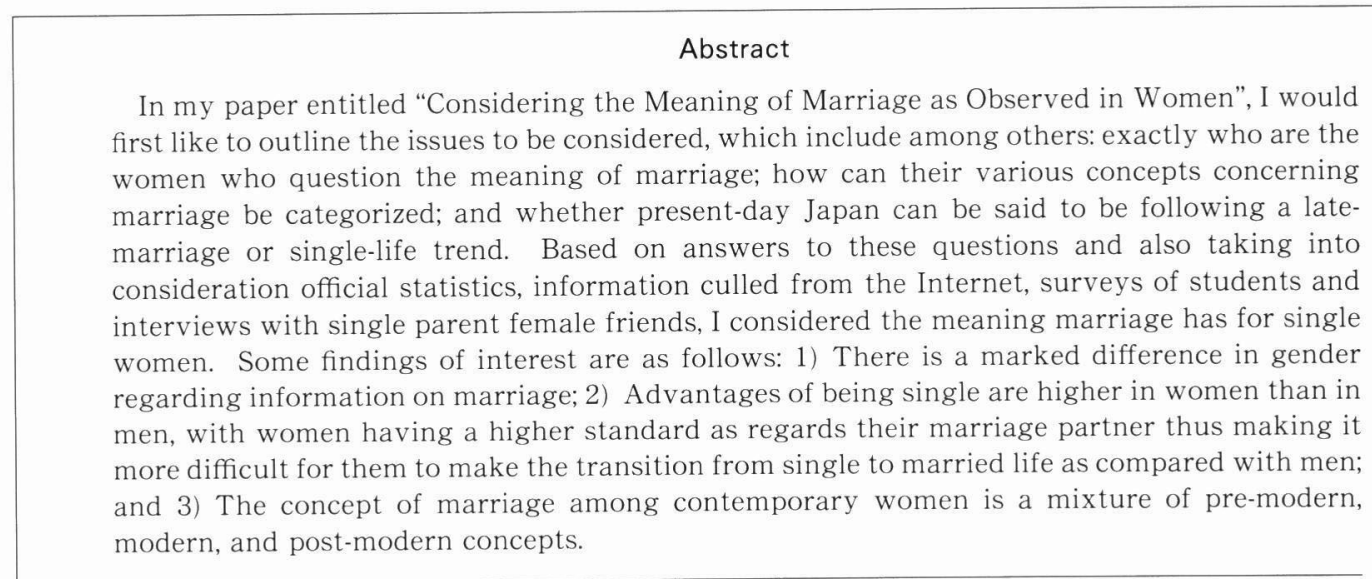

Key words: women, meaning of marriage, difference in gender 


\section{口 1.「結婚」を論じるうえでのいく つかの疑問}

第 13 回大会シンポジゥムにおいて,「女性にみ る結婚の意味を問う」の私の報告では, 他の報告 者の報告内容と重複することなく，しかも相互の 関連づけを考慮するなら, 現代日本の都市社会に 焦点をあてた内容とするのが妥当だろうと考え た。しかし，報告準備をするなかで，「女性にみる 結婚の意味を問う」うえでの疑問が次々と浮かん できた。はじめに，それらの疑問を「女性にみる 結婚の意味を問う」検討課題として整理しておこ う。

まず第 1 に,「女性にみる結婚の意味を問う」べ き“女性”之は，どのような女性のことかという 疑問である。たとえば, 国立社会保障・人口問題 研究所は, 1952 年の第 2 回「出産力調查」以降, 5 年ごとに出生動向基本調査を実施し, 1982 年 の第 8 回調査からは, 夫婦調査に加えて独身者を 対象に「結婚之出産に関する全国調査」を行って 抢り，そこでは，結婚への意欲や希望の結婚像な どについてかなり詳細なデータがとられている。 しかし, 夫婦調査では, 結婚について, 初婚年齢, 出会いの年齢, 交際期間, 出会いのきっかけなど が質問されているが, 結婚の意識については一般 的な傾向が捉えられているだけである。他方， 1997 年の『国民生活選好度調査』を見ると, 未 婚・既婚あわせて結婚相手の条件を問うているも のの, 既婚者には,「結婚した時の条件」と断って 問うており，しかも残念ながら，報告書では，未 婚者之既婚者と区分した集計結果が示されていな いのである。未婚者のみならず，既婚者も，また， 離死別者も，人生の節目ごとに「結婚の意味」を 問うことがあるだろうし，ライフステージが異な れば，結婚の意味づけが異なっても不思議ではな いが，報告書からは，そのような違いは把握でき ない。少なくとむ, これらの官庁統計をみる限り, 「結婚の意味」を問うのは，人生のなかで「結婚」 という課題に直面する未婚男女に限られたことで
あるかのような印象を受ける。しかも，結婚に関 する意識調査がもっぱら独身者を対象に実施され ている背景として，「結婚は人生のゴール」であ り，「結婚は人生に 1 度のもの」といった結婚観 が垣間見える。独身女性だけが「結婚の意味を問 う」のにふさわしく，既婚女性や離死別女性に とっては“無意味”か, “手遅れ”之考えられてい るかのようであるが，果たしてそうなのだろう か？なによりも，末婚・既婚を問わず，少なく之 屯, 16 歳以上のすべての女性を対象とする「結婚 の意味」を問うデータが欲しい。

第 2 に, 結婚の意味づけや結婚相手の条件につ いては,「結婚之出産に関する全国調査」の独身者 調査でも, 時系列的にデー夕がとられているが, 「結婚」の意味や質問項目および選択肢の意味自 体を再考する必要があるのではないかという疑問 である。現代人は,「結婚」を, 法律婚のみと理解 しているのか, あるいは, 非法律婚も含めて理解 しているのだろうか。また, 1997 年の調査報告 書による之, 結婚の利点については, 男女之も 「精神的な安らぎの場が得られる」が最屯多く, 男 女で比率の差もみられないようであるが，「精神 的な安らぎの場が得られる」ことの意味は, 果た して男女で同じなのだろうか。同様に, 結婚相手 の条件として, 第 1 位は, 男女ともに「人柄」で あり, 第 2 位として, 女性の「経済力」, 男性の 「容姿」を大きく引き離しているが, 結婚相手の条 件として，よ゙のような「人柄」を希望するかとい う具体的内容では，かなり男女差があるのではな いだろうか。さらに，男女の結婚観の違いについ て, 山田昌弘氏が指摘するように, 「男性は, 自分 より屯学歴, 職業ランク, 就職先の企業規模, 年 噛が低い女性を求め, 女性は，自分プラス自分の 父親よりも, 学歴, 職業, 企業規模が高く, 自分 よりも年齢が高い男性を求める傾向がある」なら ば，男女それぞれの「身体化した性役割分業」意 識の違いと, 結婚の意義づけや結婚相手の条件の 違いとの関連についても検討する必要がありそう だ（山田，1996）。 
第 3 に，上記の報告書によると，男女ともに， 高学歴の者ほど相手の条件を重視, または, 考慮 する割合が高くなっており, 結婚の意味づけや結 婚相手の条件については, 同性内での格差が想定 されるが，女性の階層とさまざまな結婚観との関 連はよ゙うかという疑問である。たとえば，近年， 増加傾向にある，10 代で “できちゃった結婚”を する女性たちは, 結婚をどのように意味づけ, 結 婚相手としてどのような条件を期待したのだろう か? 恋愛, セックス, 同棲, 婚姻, 出産, 相手の 条件など, 結婚観の相違にみる女性類型を捉える ことも重要な課題である。

第 4 に, “できちゃった結婚” の増加と屯関連 するが,「子どもを産むなら, 結婚してから」とい う意識のみならず,「結婚したら束縛される」,「結 婚したら相手に養ってもらう」という結婚イメー ジをむっている未婚女性が少なくないが, 結婚イ メージがこのように“旧態依然”ししているのは, どうしてなのかという疑問である。あるとき, 一 人の女子学生が,「母親は,『結婚は人生の墓場や』 之言うんです。そうなんですか?」上質問してき た。未婚女性の結婚イメージの形成に影響を及ば している諸要因を探るうえで, 親世代が娘に伝え る結婚情報について検討が必要である。のみなら ず，未婚女性をターゲットとしてマスメディアか ら流されている結婚情報について検討することも 必要だろう。

ついでながら，「結婚の意味」を問ううえで， ジェンダー差に関係なく共通した素朴な疑問を呈 したいと思う。

第 5 に,「結婚」という場合,「結婚する・結婚 しない」,「結婚している・結婚していない」,「結 婚経験あり・結婚経験なし」といった区分をすべ て含むけれど，これらの区分のどこに焦点をあて るかによって, 論点が異なってくるが, これらの 区分を考慮しながら,「結婚」について議論する必 要があるのではないかという疑問である。

第 6 に, 近年, しきりに, 少子高齢化之“晚婚 化・未婚化”が関連づけられ, あたかも“晚婚
化・未婚化”が “社会問題”であるかのような論 調が少なくないが, 果たして, 現代社会は,「晚婚 化・未婚化」社会なのかという疑問である。厚生 労働省の人口動態統計によると, 1950 年の平均 初婚年齢は, 男性 25.9 歳, 女性 23.0 歳だったも のが, 2001 年には男性 29.0 歳, 女性 27.2 歳之, この 50 年間にそれぞれ結婚年齢が 2.9 歳, 4.2 歳 上昇している。しかし，1950年から 2001 年まで の約 50 年間に, 男性の平均寿命は 58.0 歳から 78.1 歳へと約 20 年長くなり, 女性では 61.5 歳 から 84.9 歳へと 23.4 年長くなっており, 単純に 計算すると, 結婚後の人生は, 男性では 17 年, 女 性では 19 年長くなったことになる。平均寿命の 延びから初婚年齢の上昇をみると, 到底, “晚婚 化”之は言えない。また，未婚化についても，生 涯未婚率が徐々に高くなっているとはいえ, 少な くと屯男性の 8 割, 女性の 9 割は結婚している。 しかも, 一人ひとりの生涯における夫婦生活年数 の平均值は, 既婚率の高さ, 離婚率がまださほよ゙ 高くないこと, そして, 平均寿命の長さから推測 して，おそらく，わが国は世界一長いのではない だろうか。“未婚化”という解釈についても再考が 必要だ。

本稿では, 既存の官庁統計, インターネットか らの情報, 身近にいる学生たちゃ“子連れシング ル”の友人・知人たちからの聞き取りデータを踏 まえて, 未婚女性に限定して, 可能な限り, 結婚 の意味について考察する。

\section{口 2. 「結婚」情報におけるジェン ダー格差}

書店に行くと,『ゼクシー』のような結婚情報誌 のみならず, 恋愛や結婚をテーマにした一般書が 数多く並んでいる。また，いわゆる結婚シーズン ともなると週刊誌やファッション雑誌など屯結婚 特集を組み, 結婚情報が氾濫する。しかし, これ らの雑誌や書籍の大半が, 未婚女性をターゲット にした内容になっており, 男性向けの結婚情報誌 や一般書を探すことは難しい。マスメディアなど 
からの結婚情報のターゲットは, “若い”未婚女性 であり,ジェンダー差のみならず, 年代差も顕著 である。しかも, それらの内容は, 結婚式の“華 やかさ”や“幸福”イメージのみを振りまいてい る。人生における結婚の重みが男女で違うかのよ うな捉え万に対する疑問は, 微塵も感じられない あのが少なくない。

「結婚情報」を広義に捉えると, 好むと好まざる とにかかわらず, 男性よりも女性のほうが, マス メディアからの結婚情報のみならず, 育ちのなか で, たとえば, 結婚式, 花嫁衣装, 婚礼家具, 改 姓, 退職, 出産, “八イミス”, シングル・マザー など，同性の結婚情報に触れる機会が多いに違い ない。これらが, 結婚情報の可視性・話題性にお けるジェンダー差となり, また, それゆえに,「女 性によっての結婚とは?」,「女である自分によっ ての結婚とは?」など，「結婚」を考える機会の ジェンダー差にもつながりやすい。しかも，ここ で押さえておきたいことは, 結婚に扔ける“華や かさ”のジェンダー差のみならず, 結婚すること による不利益や拘束感のジェンダー差, さらに, 「結婚のマイナス」に対する感度のジェンダー差 あ，ようやく顕在化してきたこよである。

それでむ，「女は結婚したがっているというこ とになっている」（姫野，2000）という前提に基 づくマスメディア情報が氾濫し,「男性にとって 結婚はイベント，女性にとっては生まれ变わり」 （山田，1996）といった“説得力のある”“わかり やすい”説明が, 専門家の間でもなんとなく支持 され, 知らず知らずのうちに,「結婚の重みは男女 で違う」という意味づけが確たるものとイメージ され，そして，マスメディアは，相む変わらず， “若い”未婚女性をターゲットに結婚情報を流し 続ける。

実際には, マスメディアなどからの情報は, 専 ら「消費としての結婚」に関するもので, 生き方 の羅針盤となる情報は乏しく，加藤春恵子氏のい う「情報砂漠」（加藤, 2001）が実態であっても, だからこそ，“役に立つ”“生き方の指針になる”
情報を求める女性は後を絶たず, 結婚情報の提供 者之結婚情報の消費者との供給と需要のサイクル がエンドレスに続くことになるのだろう。

ついでながら, ある1日に, インターネットで 「結婚の意味」を検索すると, 実に 530 件のサイ トが列挙された。それらのサイトのなかで,「結婚 の意味」について意見交換する掲示板の“カキコ” の大半が女性であった。「カキコによる結婚物語」 は, それはそれで興味深いものがあるが, 当事者 によっては, ピア・カウンセリング的な癒し効果 がむたらされているようであり,「結婚を語る」に あ, ジェンダー差がうかがえるのである。

曰 3. 女性を取り巻く結婚の意味づけ を探る

\section{（1）官庁データにみる「女性における結婚の意 味」}

近年実施された, 結婚をめぐる官庁統計や世論 調査結果について概観する。

はじめに,「第 11 回出生動向基本調査一独身者 調査, 1997」をみてみよう。厚生労働省は, 晚婚 化・未婚化を少子化の重要な要因として捉えてお り，「なぜ，女性たちは子どもを産まないのか」と いう少子化の要因を,「子どもを産まないのは結 婚しないからだ」と捉えており, そのため, 本調 査からむ，未婚男女は「なぜ結婚しようとしない のか」という疑問を解きたいという意四が伝わっ てくる。たとえば, 結婚する意思をむつ未婚者は 90\%を下回ることが強調されている点である。具 体的には，男子 $85.9 \%$ ，女子 $89.1 \%$ である。

あう少し詳しくみると,「ある程度の年齢まで には結婚するつもり」の男子は 48.6\%, 女子は $42.9 \%$, 男女之もに半数以下であり, 逆に, 「理 想的な相手がみつかるまで結婚しなくてもかまわ ない」男子は $50.1 \%$ ，女子は $56.1 \%$ とこちらは 男女と屯過半数を超える。「結婚には利点ない」と 考えている男子 $30.3 \%$, 女子 $25.5 \%$ と多くない 屯のの, 「独身生活は利点あり」との回答は, 男子 82.7\%，女子 $88.5 \%$ ときわめて高いのである。そ 
特集 Part II 現代社会における結婚の意味を問う：女性にみる結婚の意味を問う

れでも，「男女が一緒に暮らすなら結婚すべきだ」 という考えに賛成の男子は $69 \%$ ，女子は $59.3 \%$ と高いのである。

女性たちの多くは，現在のシングル・ライフに 利点ありと考えており, 結婚生活に利点がないと は思わないが，理想の相手がみつかって，その相 手と一緒に暮らしたいと思えるならば結婚したい ということのようである。

上記のデータにおいて,「独身生活は利点あり」 之考えている男女は圧倒的な多数であり, 彼ら彼 女たちの多くは, 山田昌弘氏のいう“パラサイト シングル”ライフをエンジョイしているのだろ う。ところで,「第 2 回家庭動向調査 1998」によ ると，パラサイトシングルは，男性よりも女性に 多く，とりわけ，母親に「身の回りの世話」をし てもらっている成人した男性は $51.8 \%$, 成人した 女性では $73.1 \%$ と非常に高い数值になっている。 また，「経済的支援」を受けている成人した男性 は $29.7 \%$ ，成人した女性は $39.8 \%$ である。

わが国において，パラサイトシングルの男女の 比率が結構高く, 彼ら彼女たちが, 結婚したいと 強く突き動かされることがなく，独身生活を送る ことに何ら支障はないという事態に変化がない限 り,“パラサイトシングルの時代”は, 当分続きそ うである。

女性についていえば，パラサイトシングルの比 率が男性より高く，それだけ，独身生活の利点が 男性より屯高く，結婚の理想の相手へのこだわり が男性よりあ高い分, 独身生活から結婚生活へ乗 り換えるという選択を, 男性以上に難しくしてい ると解釈できる。

さらに, わが国では, まだまだ, 女性たちの結 婚をめぐる多様な生き方を認めようとしない風潮 が強いことを,「第 2 回全国家庭動向調查 1998」や「朝日新聞世論調查」(2003.6.27 付)に みることができる。

すなわち,「結婚せずに, 1 人で生きていくこと に共感しない」,「結婚せず，1 人で子どあを産ん で育てることに共感しない」,「結婚したら子ども
はもつべきだ」,「子どもが小さいうちは母親は育 児に専念したほうがよい」，「結婚したら自分のこ とを犠牲にしても子どものことを優先すべきだ」 といった考え方に対して，世代が高いほど圧倒的 多数の支持を得ているのである。未婚男女との意 識のずれは顕著である。そして，未婚の男女にす れば，未婚でいるうちは，さほど風当たりは強く ないが，一度結婚すると，周りから上記のような 考えを押しつけられてはたまったものではない。 社会全体で, 結婚観についての規制緩和があっと 進めば，未婚男女が，少しは結婚に踏み切りやす くなるかあしれない。

しかも，女性たちが，結婚後も出産後も仕事を 続けたいと思っていても, 現在の職場で, 結婚後 あ出産後むフルタイムで働いている同僚がきわめ て少なければ, 安心して, 結婚に踏み切れないの あ当然と言える。ちなみに, 結婚後も, 子育てし ながらフルタイムで㗢いている女性の割合は, 「第 12 回出生動向基本調查一夫婦調查 2002」 をみると, 表 1 のように, 結婚年数が $0 \sim 14$ 年ま でで，子どもがいて，正規雇用で働いている女性 は $15 \%$ に満たないのである。しかも, 結婚後む仕 事を続けながら，子どもを産み育てたいと思って も, 松本・瀬川氏が指摘するように,「自分が受け たような，専業主婦的な育児しかイメージできな いと, 仕事との両立は不可能で尻込みすることに なる」(松本・瀬川，1998）だろうし，3 歳児神話 への執着や子どもを保育所へ預けることに抵抗が あると,なおさらだ。

とはいえ, 女性たちの多くが, 結婚, 出産後む 継続して働きたがっているのかというと, どうあ そうとも言えない。1998 年に出された『厚生白 書』によると, 女性の結婚の条件が，かつての 3 高から, 3C (comfortable, communicate, cooperative) に代わってきたと指摘されており，結婚 後に期待するライフスタイルは,「男は仕事と家 事, 女は家事之趣味 (的仕事)」の新・専業主婦志 向なのだそうである。このような新・専業主婦志 向の女性のなかで, 理想の相手と結婚し, 希望ど 
表 1 結婚持続期間別にみた, 妻の就業状態およひ子どもの有無の構成

\begin{tabular}{|c|c|c|c|c|c|c|c|}
\hline \multirow{4}{*}{ 結婚持続期間 } & \multirow{4}{*}{$\begin{array}{c}\text { 標本数 } \\
\text { (2002 年) }\end{array}$} & \multicolumn{6}{|c|}{ 妻の就業状態 } \\
\hline & & \multicolumn{4}{|c|}{ 就業 } & \multirow{2}{*}{\multicolumn{2}{|c|}{ 専業主婦 }} \\
\hline & & & & \multicolumn{2}{|c|}{ 正規雇用（再掲） } & & \\
\hline & & 子なし & 子あり & 子なし & 子あり & 子なし & 子あり \\
\hline $0 \sim 4$ 年 & $1,281(100 \%)$ & $26.6 \%$ & $18.1 \%$ & $17.5 \%$ & $10.7 \%$ & $13.0 \%$ & $41.3 \%$ \\
\hline $5 \sim 9$ 年 & $1,160(100 \%)$ & $6.8 \%$ & $34.1 \%$ & $2.9 \%$ & $13.9 \%$ & $3.8 \%$ & $54.3 \%$ \\
\hline $10 \sim 14$ 年 & $1,124(100 \%)$ & $3.6 \%$ & $55.5 \%$ & $1.5 \%$ & $15.5 \%$ & $1.6 \%$ & $38.2 \%$ \\
\hline
\end{tabular}

出典：国立社会保障・人口問題研究所 2003「第 12 回出生動向基本調査一結婚と出産に関する全国調査 夫婦調 查の結果概要」13 頁をむとに作表.

おりの生活を送ることができるのは，果たしてど の程度だろうか？実現可能性が低いとなると, そのこともまた，女性たちにおける結婚を躊躇さ せる要因の一つになっていると言えるだろう。

\section{（2）「女性にみる結婚の意味」をめぐる言説}

近年，上記のような結婚をめぐる官庁統計など から明らかにされてきた知見は, 結婚への積極的 な動機づけの弱まりと独身生活のメリットについ てである。男女ともに, 人生における結婚のウェ イトが低下したことは確かである。

にもかかわらず, わが国の場合, 女性に限らな いかもしれないが, 結婚に関わる意識調査などで は，未婚者に対して，「なぜ結婚するの?」と問う よりあむしろ,「なぜ結婚しないのか？」という問 いから出発することが少なくない（ジョーンズ＆ ウォーレス, 1996; ニッセイ基礎研 1998; 松 本・瀬川, 1997)。(ほっといて。私の勝手で しょっ!)という，うんざり気味の声が聞こえて きそうである。

女性たちの結婚のイメージについて，あう少し 詳細に検討していくと, 結婚へと踏み切れなくさ せている要因のいくつかが見えてくる。

姫野カオルコ氏は, マスメディアが女性の結婚 願望を煽っている現状について，「(女性たちが） よ゙う結婚したいのかが見当たらない。結婚という 語が『どのような行為』『゙゙のような生活』を指し ているかむなく，もちろん『どんな人とどんなふ
うに』という部分もまったくない,ただ漠然と, （女性は）『結婚したい』と思っている」というの が, マスメディアの論調であると批判する（姫野, 2000)。そして,「結婚というのは, 誰かと恒常的 にセックスをする生活である」にもかかわらず, 「20 歳を過ぎると, 親や親戚が, それを急に勧め るわけだ。おかしなものだ」, と喝破する（姫野, 2000)。全く同感である。

女性たちの結婚の条件について, 松本・瀬川氏 によると, 高学歴女性ほよ゙,「仕事ができる人」で 「家事ができる人」といった, 旧来の価值観と新し い価值観とを共有しているという（松本・瀬川, 1998)。しかし，単に期待水準が高いだけではな く, 条件の狭さむハードルを高くする要因になっ ているのである。また，女性たちが，しばしば, 理想の異性の条件としてあげる「話が合う人」, 「居心地のいい人」というのは, 理想が高すぎると はいえないものの, 実のところ, 個々の女性に とって, どんな異性なら「話が合う」のか, どん な異性なら「居心地がいい」と思えるのか, その 点ははっきりしておらず, 出会ってみないとわか らないというのがホンネなのである。いうなれ ば，自分にとって「話が合う人」，自分にとって 「居心地のいい人」を探しながら，“自分探し”を しているのである。“自分らしさ”が見つからない うちは, 自分に合う相手をみつけにくいのあ当然 と言えば当然だ。

ところで, 未婚女性が, 結婚に強く「必要性」 
を感じる一っのきっかけとして，近年，“でき ちゃった結婚”が増加傾向にあること，また，「結 婚している女性では, 結婚というものと母親役割 を担うことを結びつけて意識している」(第 12 回 出生動向調査, 2003: 19）といった知見を踏まえ ると,「子どあを産みたい時」という要因をあげる ことができる。そうであれば,「子どあを産みたい 時」を結婚の契機と考えている女性にとっては, 出産可能年齢の間は,「まだ結婚を急ぐことはな い」のであり，「子どあを産みたいと思えない」 と, 結婚への動機づけは高くならないとあ言え る。

また，吉岡しげ美氏が，女子大生に対する意識 調査から見いだした,「(彼女たちは, ) 結婚はした いが，結婚によって自由が奪われるのは嫌」（吉 岡, 2003）という経験的一般化命題についても, データの代表性は保証されないが，しごく当然と 思われる。

\section{（3）未婚女性にみる結婚イメージの新旧}

現代の未婚女性の結婚観について, 学生に対す るアンケートやインターネットから検索した結婚 に関する“カキコ”などから得られた情報を検討 してみると, 多くの女性たちの結婚イメージのな かには, 前近代的な家制度下の結婚イメージ, 近 代家族制度下の結婚イメージ, ポスト近代家族へ と踏み出した結婚イメージが混在している状況を 読み取ることができる。

まず指摘できることは, セックスと結婚は別で あるという意識の一般化であり, 近代型の結婚の 特徴であった, 恋愛・結婚・セックスの三位一体 は，ほぼ解体したと解されることである。また, 未婚者においては, 複数の異性と関係をむつこと についても抵抗感がなくなり, 結婚へと踏み切れ ない一因として，「相手を 1 人だけに特定できな いから結婚できない」という意見が, 決して特異 ではないことである。しかし，そのことは，未婚 のセックス・フリー化ではあっても, 同時に, 結 婚後の一夫一婦制を当然のように受容しているこ
とを示してもいる。ある女性は,「彼の自由恋愛を 封じ込めるために結婚したい」という。いうなれ ば, ポスト近代型の恋愛と近代型の結婚の共存で ある。

ところで，未婚女性の多くは，いずれ結婚した いとは思っているが, なぜか, 結婚とは, “籍を入 れること”という通念がまかりとおっている。婚 姻とはいわず, “入籍”なのである。戦後に民法改 正がなされてすでに 50 年以上経っているにあか かわらず，なぜ，前近代的な “入籍”か？と，あ きれるばかりであるが，芸能情報の影響が少なく ないだろう。“籍”にこだわるつもりはないが, し いていえば, “創籍”のほうが，まだましだ。

また，結婚生活のイメージが，実に旧態依然と していることにも驚かされる。私は毎年, 家族社 会学の授業のなかで, 学生たちと, 恋愛と結婚の 違いについて話し合うのだけれど, 自由で楽しい 恋愛のイメージに対して, 結婚については, 「我 慢」,「束縛」,「家と家との関係の煩わしさ」,「嫁 姑関係がある」,「家事が嫌」といったマイナスイ メージの意見が圧倒的に多いのである。そして, 学生たちには, このようなマイナスイメージの結 婚への忌避感はあっても, 新しいカップル関係を 作り出すといった変革意識はそしい。それでも, 受講終了時には, 結婚観の摇らいでいる学生が増 えるのは, ささやかな喜びである。

さらに，未婚女性の多くは，まだまだ，“嫡出 子”へのとらわれが強いことを指摘できる。セッ クスは自由, しかし, あし妊娠したら, 出産する 前に婚姻届を出したいという思いが, “でき ちゃった結婚” の増加につながっているが，この ことは,「婚内子」「父親のいる子」へのこだわり の反映でもある。「子どもを産むなら婚姻届を出 してから」という未婚者の意識は,「子どあが欲し いから結婚したい」という意識と合致するだけで はなく,「結婚しないなら，子どもを産むべきでな い,「結婚したら子どもを産んで “当たり前”」と いう世間の風潮を内面化した結果なのかもしれな いが,これらの意識が, 意図するしないにかかわ 
らず,「結婚しているのに出産しないのは“おかし い”」という強迫観念の温存に寄与し，「婚外子」 差別を容認する結果にもなっていることを指摘し ておきたい。

\section{（4）現代女性の結婚志向を左右する原因説明図式}

以上の考察をあとに，現在の未婚女性たちにお ける，なぜ結婚するのかしないのか？という，な ぜにあてはまる要因について, 図 1 のような「原 因説明図式」を描くことができる。

(1)マスメディアからの結婚情報は氾濫しているも のの，当事者にとって，人生の「羅針盤」とな るような，結婚情報はそしい。

(2)未婚女性たちからみて, 人生の先輩たちは, 果 たして，幸せな結婚生活を送っているようにみ えるのだろうか? 未婚女性からみて, 最む身 近な女性である母親たちが, 必ずしも人生のモ デルとは思えないだけでなく, 人生のモデルと なるような女性が身近に少ない。

(3)未婚女性たちの多くは, いずれは結婚したいと
思っているが, 同時に, 未婚でいることに困っ ていない。性関係にもこだわりはない。それだ けに，未婚でいることのメリットが大きく，未 婚でいることを居づらくする要因が少ない。 〈引き留め要因〉の強さである。パラサイト可能 性も未婚への〈引き留め要因〉になっている。

(4)友だちが次々と結婚したり, 親が結婚を急がせ るなど，未婚でいることが居心地悪く思える事 態は, 結婚への〈押しの要因〉となる。親によ る拘束が強いといった条件む〈押しの要因〉と なるだろう。

(5)「一緒に暮らしたい」「いつむ一緒にいたい」と いう理由が結婚への〈引きの要因〉になる。「一 緒に暮らしたい」「いつも一緒にいたい」という 理由から, 同棲を選ぶ人もいる。ただし, 同棲 経験率は $5 \%$ 程度と低い。未婚男女の多くは, 同棲に否定的な親や親墄と揉めるよりは，結婚 するほうが楽だという。

(6)結婚したいと思う気持ちがあっても, 結婚する と，さまざまな束縛や我慢することがありそう
(1)〈マスメディアからの結婚情報〉

「消費」としての結婚情報の氾濫

「羅針盤」としての結婚情報は？
(2)〈同性たちの結婚ライフは?〉

母親のような生き方 NO

仕事と家庭を両立している女性モデルは? 既婚女性は幸せそう?

シングル・マザーの現状は?

(5)〈引きの要因〉

(6)〈押し戻し要因〉

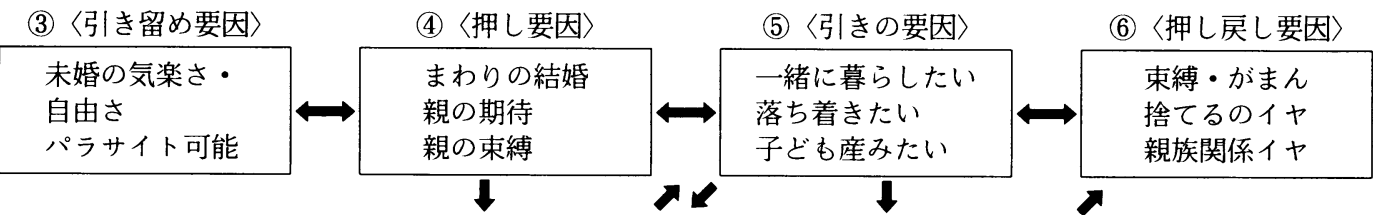

(7)〈引き金要因〉

\begin{tabular}{|l|}
\hline 妊娠という事実 \\
プロポーズ \\
\\
彼の自由恋愛を封 \\
じ込みたい
\end{tabular}

(8)〈通路づけ要因〉

(9)

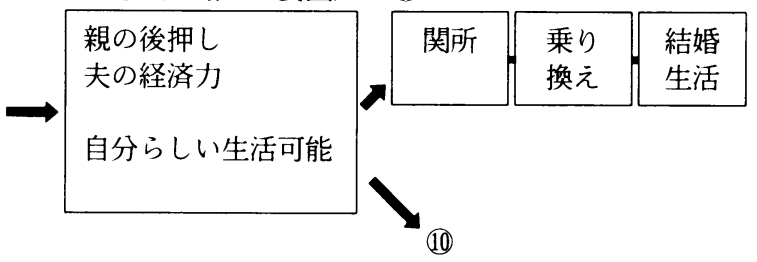

ポスト近代結婚?

図 1 現代の未婚女性における結婚する理由に関する原因説明図式 
で踏み切れない。名前を捨てたくない, 仕事あ 辞めたくないと思うと, 踏み切れない。家と家 の関係が煩わしいと踏み切れない。彼の気持ち が煮え切らないと踏み切れない。これらは，未 婚への〈押し戻し要因〉とみなすことができる。 (7)妊娠は，結婚を決断する契機となる。結婚への 〈引き金要因〉である。しかし，妊娠がすべて結 婚につながるわけではなく, 結婚への〈引きの 要因〉が乏しかったり, 結婚への〈通路づけ要 因〉が不十分であったりすると, 中絶という手 段が選ばれることにもなる。彼の自由恋愛を封 じ込みたいという思いの顕在化む〈引き金要 因〉とみなせるだろう。

(8)親の後押し, 夫の経済力, 自分らしい生活の見 通しがたつことなどが, 結婚への〈通路づけ要 因〉となる。

(9)男性の場合, 結婚とは, トンネルか鉄橋を通過 するようなもので, 結婚前と結婚後と, 同じ列 車で連続した線路を走ることに変わりない。し かし, 女性の場合, 結婚とは, 関所を通過する ようなもので, 結婚前には, 関所の向こう側の 結婚後の生活は, なかなかみえないし，わから ない。しかも，多くの女性は，関所を通過する と, 列車の乗り換えを期待される。従来, 女性 たちは, 結婚後は, 夫の列車に乗り換えて, 運 転手である夫に行く先を委ねることが期待され たのである。この乗り換えが嫌なら，結婚を思 い留まるというのが一つの選択肢である。

(11)しかし, 今, “ポスト近代結婚”という多様な選 択肢が浮かび上がってきた。女性にとっても， 結婚がトンネルや鉄橋になって, 結婚前のこち ら側から結婚後の向こう側が見渡せて, 乗り換 えなしで, 夫の列車と並行して走ったり, 連結 して走りながら，いつであ引き返しやリセット ができればいいのかむしれない。

\section{（5）末婚女性の多様な結婚意識と実態を問う}

現代の未婚女性といっても，十把一束に語るこ とはできない。少なくとも, 階層の違いによって,
結婚をとりまく状況が異なることが予想される。 そこで, 学歴と現職との違いにより, きわめてお おざっぱではあるが，未婚女性の階層差からみた 結婚事情を類型的に描いてみることにした。

(1)大卒・キャリア女性の結婚事情一一現在のわが 国では，男性と同等の働き方をしていては，到 底，仕事と家庭とを両立できそうにない。しか あ, 職場によっては, 子育てしながら, フル夕 イムで㗢いているモデルとなる女性は少ない。 結婚後も仕事を継続している人びとの職種は, 公務員, 教員, 専門職などに限られている。そ のため, 結婚と仕事と両立できそうになけれ ば, 結婚を先延ばしするか, 結婚しても出産を 先送りすることになるだろう。コミューター婚 という選択むある。それとも, “将来有望な夫” に賭けて退職する?

(2)大卒または短大卒で一般職女性の結婚事情— 彼女たちの仕事は, 働きがいのある仕事とは必 ずしもなりえず, 年数が経つほど, 同期の男性 との差が顕著になる。しかし,「生活水準を低下 させ，自分の自由を放裹してまで」結婚したく ない。なによりも，3C 条件を満たす男性との結 婚希望が強い。その場合, ぞこで妥協するかだ ろう。とはいえ,「結婚しないかもしれない」と いう選択のために，キャリア・アップをめざ し，貯蓄もする。

(3)大卒または短大卒で派遣社員の結婚事情——彼 女たちの仕事は, 不安定で使い捨てされやすい ため, 長く働き続けることは期待できない。結 婚退職を前提で働いている人が少なくない。 3C 条件を満たす男性との結婚を希望しながら あ, 子どあが産まれたら, 育児に専念したいよ あ思っている。他方で, 必ずしも結婚に期待せ ず，派遣で働きながら，キャリア・アップをは かっている人たちもいるが, 実現は容易ではな い。

(4)高卒でサービス職, フリーターの結婚事情—— 彼女たちは, 現在の仕事を長く続けたいとは考 えておらず，多くがお金を稼ぐために働いてい 
る。恋愛願望と結婚願望は高い。この層で, 妊 娠中絶や，“できちゃった結婚”が増加してい る。十代で“できちゃった結婚”をすると，夫 婦いずれかの親元に，夫婦で依存する“パラサ イト・カップル”になる可能性が結構高い。将 来の自立が重要な課題である。

\section{4.「女性にみる結婚の意味を問 う」,これから?}

本稿の最後に,「結婚の意味」を問うなかで, 浮 かび上がってきたさらなる課題を列挙して, 結び に代えたい。

(1)ライフスタイルの多様化が主張されながら，な ぜ，日本社会で，多様な生き方・多様な “結婚” が差別されることなく認められないのだろう か? という，「なぜ」の解明である。

(2)女性の階層格差と結婚事情から不平等社会日本 の実態に迫ることができそうだ。

(3)現行婚姻制度が, 結婚差別を生み出すメ力ニズ ムを解明することである。

(4)さまざまな女性たちの現地点から，脱近代型ラ イフスタイルの選択を可能にする “羅針盤”を 提案することである。

(5) とはいえ, 家族社会学の立場から, 現代人の 「結婚の意味」を検討するための調査・研究が きわめてそしい現状を打開することが，なによ りの緊急課題である。

\section{【参考文献 ・参考資料】}

朝日新聞世論調查, 2003.6.27 付 (6月 8, 9 日実施 有 権者対象 面接法 無作為二段抽出法 回收数 1949 人回収率 $65 \%$ ).

汇原由美子, 1994,「結婚しないかもしれない症候群」 『家族社会学研究』6:37-44.

姫野カオルコ，2000,『みんな，どうして結婚してゆく のだろう』集英社.

伊田広行, 2003,「シングル単位視点からみえる「結婚」 上「恋愛」」『家族社会学研究』14-2: 13-22
岩上真珠, 2003,『ライフコースとジェンダーで読む家 族』有斐閣.

ジョーンズ, G., ウォーレス, C., 宮本みち子監訳, 1996, 『若者はなぜ大人になれないのか』新評論.

加藤春恵子, 2001,「脱家父長制的結婚モデルを求めて 一現代日本社会の情報砂漠を超えるために一」東京女 子大学女性学研究所, 小檜山ルイ, 北條文緒著『結婚 の比較文化』勁草書房, 241-272.

風間 孝, 2003,「同性婚のポリティクス」『家族社会学 研究』14-2, 32-42.

国立社会保障 - 人口問題研究所, 1998, 『第 11 回出生動 向基本調査一結婚と出産に関する全国調査』（1997 年調查 18 加 50 歳の独身者 12553 票 9407 票 回収・回収率 $74.9 \%$ ).

国立社会保障 - 人口問題研究所, 1999, 『第 2 回全国家 庭動向調査結果の概要』(1998 年 13630 票 有効 回収数 11951 票 回収率 $87.7 \%$ 有配偶女子 7578 票について分析).

国立社会保障 - 人口問題研究所, 2003, 『第 12 回出生動 向基本調査一結婚之出産に関する全国調査一大婦調 査の結果概要』（2002 年実施，50 歳未満の有配偶女 子 9021 人, 有効票 7916 人 回收率 $87.8 \%$ ).

松本真澄, 瀬川祥子, 1998, 「晚婚化 - 非婚化一30 代女 性はなぜ結婚しないのか」『岐阜を考える』岐阜県産 業経済研究センター。

望月 蓠, 2003,「結婚をよ゙うとらえるか」『家族社会学 研究』14-2: 23-31.

内閣府国民生活局編, 2002, 『平成 13 年度国民生活選好 度調査一家族と生活に関する国民意識一』(2001 年 実施 15 歳以上 80 歳未満男女 5000 人 層化二段 無作為抽出法 個別訪問留め置き法 有効回収数 3988 人 回収率 $79.8 \%$ ).

内閣府国民生活局編, 2002, 『平成 13 年度国民生活白書 一家族の暮らしと構造改革』ぎょうせい.

山田昌弘, 1996,『結婚の社会学』丸善.

山田昌弘, 2000,「結婚の現在的意味」善積京子編『結婚 とパートナー関係』ミネルヴァ書房, 56-80.

吉岡しげ美, 2003,『花嫁人形@幸せのゆくえ一日暮机 ちゃいない私たちへ一』新読書社。

善積京子, 2003,「〈近代結婚〉の摇らぎ一スウェーデン 社会からみた結婚の意義一」『家族社会学研究』14-2: 43-53. 